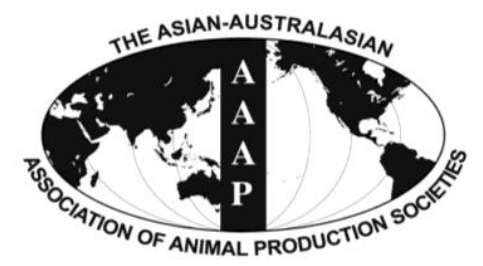

Asian Australas. J. Anim. Sci.

Vol. 26, No. 10 : 1406-1415 October 2013

http://dx.doi.org/10.5713/ajas.2012.12703

www.ajas.info

pISSN 1011-2367 elSSN 1976-5517

\title{
Neutrophil Functions and Cytokines Expression Profile in Buffaloes with Impending Postpartum Reproductive Disorders
}

\author{
Manas Kumar Patra ${ }^{1,3, *}$, Harendra Kumar ${ }^{1}$, and Sukdeb Nandi ${ }^{2}$ \\ ${ }^{1}$ Division of Animal Reproduction, Indian Veterinary Research Institute, \\ Izatnagar- 243122, Bareilly, Uttar Pradesh, India
}

\begin{abstract}
The study was conducted to correlate the periparturient immune status in terms of neutrophil functions and cytokine expression in peripheral blood mononuclear cell culture with impending postpartum reproductive disorders in buffaloes. Forty pregnant buffaloes were observed for occurrence of postpartum reproductive disorders (PRD), i.e., metritis, endometritis and delayed uterine involution etc., during one week prepartum to four weeks postpartum period. A representative number $(n=6)$ of buffaloes that did not develop any PRD were included in group I (healthy, control), while the animals which experienced PRD were assigned into group II $(\mathrm{PRD}, \mathrm{n}=8)$. The blood samples were collected at weekly interval from one week prepartum to four weeks postpartum period considering the day of calving as 'd 0 '. Differential leucocytes counts, superoxide and hydrogen peroxide production activity in isolated neutrophils and the mRNA expression profile of cytokines i.e., IL-2, IL-4 and IFN- $\gamma$ in PBMC culture were studied in all the samples. A higher total leucocytes, neutrophil and band cells count along with impaired neutrophil functions i.e., lowered level of production of superoxide and hydrogen peroxide before parturition and during early postpartum period were observed in buffaloes developing PRD. Further, a lower expression of IL-2, IFN- $\gamma$ and IL-4 mRNA in PBMC culture was observed at calving in buffaloes that subsequently developed PRD at later postpartum. Thus, suppression in neutrophil function and cytokine expression at prepartum to early postpartum period predisposes the buffaloes to develop postpartum reproductive disorders. Hence, monitoring of neutrophils function and cytokine expression profile would be effective to predict certain reproductive disorders at late pregnancy or immediately after parturition in buffaloes. In future, this may be a novel approach for determining suitable management and therapeutic decisions for prevention of commonly occurring reproductive disorders in farm animals. (Key Words: Reproductive Disorder, Neutrophil Functions, Lymphocytes, Cytokine Expression, Postpartum Buffalo)
\end{abstract}

\section{INTRODUCTION}

The onset of uterine infection at postpartum period precludes recovery of ovarian function, uterine involution and fertilization; prevent successful implantation and development of viable embryo leading to a large proportion of unsuccessful pregnancy (Semambo et al., 1991). The exact cause of these disorders is difficult to ascertain. It is necessary to assess the risk factors for impending postpartum reproductive disorders during pregnancy or at

\footnotetext{
* Corresponding Author: Manas Kumar Patra. Tel: +91-3862247241, Fax: +91-3862-247241, E-mail: drmanas01@gmail.com

${ }^{2}$ Centre for Animal Disease Research and Diagnosis, Indian Veterinary Research Institute, Izatnagar- 243122, Bareilly, Uttar Pradesh, India.

${ }^{3}$ ICAR Research Complex for NEH region, Nagaland Centre, Jharnapani, Medziphema, Nagaland-797106, India.

Submitted Dec. 19, 2012; Accepted May 3, 2013; Revised Jun. 4, 2013
}

early postpartum period. The annual incidence of uterine infections in postpartum animals ranges from 10 to $50 \%$ in dairy cattle (Lewis, 1997) and 20 to $75 \%$ in dairy buffaloes (Usmani et al., 2001). The establishment and persistence of uterine infections are dependent on uterine defense mechanism (Hussain, 1989). Major shifts in plasma concentration of steroid hormones including estrogen, progesterone, glucocorticoids, and arachidonic acid metabolites near the onset of parturition have been proposed to play a vital role in suppression of important leucocytes function (Cai et al., 1994), and render the animal more prone to uterine and mammary infections (Hoedemaker et al., 1992). The phagocytic capacity of neutrophils remains high throughout the peripartum period but the killing capacity is impaired (Hussain and Daniel, 1992). Decrease in neutrophils activity during the peripartum period has been suggested to influence the occurrence of uterine infections in cows. However, there is dearth of available 
literature on neutrophil cell function in relation to occurrence of postpartum reproductive disorders in buffaloes.

The lymphocyte count and functions such as cellular proliferation, antibody development and cytokine production are reduced at the time of early postpartum that may contribute to delay host responsiveness during the early stages of pathogenesis (Ishikawa et al., 1994; Detilleux et al., 1995). Immunological mechanism induced by $\mathrm{T}$ lymphocytes play important role in host defense (Hagiwara et al., 1995). Ohtsuka et al. (2004) reported that decreased $\mathrm{T}$ lymphocyte subsets (helper and suppressor/ cytotoxic) around calving make the cows susceptible to uterine infections at peripartum period. The $\mathrm{T}$ helper-1 (Th-1) lymphocytes mainly secrete IL-2 and IFN- $\gamma$ and promote cell mediated immune response. The T helper -2 (Th-2) cells mainly secrete IL-4, IL-10, IL-5 and promote humoral immunity (Seder and Paul, 1994). A balance between Th-1 and Th- 2 cell subpopulation and production of cytokines coordinates immune response to ensure pathogen elimination without causing the disease (Carter and Dutton, 1996). Impairment in cytokine expression at periparturient period may change certain immune responses and increase host susceptibility to bacterial infections. Thus, if the local and systemic immune function could be monitored during pregnancy and the mechanism leading from a prepartum immune functional deficiency to the occurrence of a crisis in postpartum period could be clarified, then an improved method of diagnosis and a better management approach to prevent postpartum reproductive diseases in dairy herds may be devised. The present study has been designed with two objectives, first to determine the periparturient neutrophil functions in relation to occurrence of postpartum reproductive disorder and second, to investigate the cytokine expression profile in peripheral blood mononuclear cells (PBMCs) culture of buffaloes developing postpartum reproductive disorders.

\section{MATERIALS AND METHODS}

This experiment was conducted on 40 pregnant Murrah buffaloes of 2 nd to 4 th parity, maintained under uniform feeding and management practices at Livestock Production and Management section, Indian Veterinary Research Institute, Izatnagar, U.P., India. The events of calving, expulsion of fetal membranes and occurrence of postpartum reproductive disorder (PRD) including metritis, endometritis and delayed uterine involution, were observed during the course of one week prepartum to four weeks postpartum period. The occurrence of metritis was adjudged based on enlarged uterus with foul smelling, watery or purulent reddish brown exudates along with rise of body temperature at three to eight days postpartum (Chapwanya,
2008). The clinical endometritis was inferred when animals were observed with purulent or mucopurulent discharge on vaginal inspection at three weeks postpartum (Sheldon et al., 2004). Uterine involution was also monitored at weekly interval by per rectal examination of genitalia from one week postpartum to till five weeks postpartum period following the method described by Custer et al. (1990).

\section{Design of experiment}

Out of 40 pregnant buffaloes observed during periparturient period, five animals were diagnosed with metritis, three with clinical endometritis concurrent with delayed uterine involution. None of the animals were suffered from dystocia or retention of fetal membrane. In this study, two experimental groups were retrospectively formed. Those buffaloes did not develop any PRD throughout the peripartum period, of which a representative number ( $n=6$ ) was included in group I (healthy), while the animals which experienced PRD were assigned into group II $(\mathrm{n}=8)$.

\section{Collection of blood samples}

The blood samples $(20 \mathrm{~mL})$ were collected in heparinized tubes from all the animals at one week before expected calving to four weeks post-calving period at weekly interval for total leucocytes and neutrophil, lymphocyte counts, neutrophil functions and PBMCs culture for cytokines assay.

Leucocyte counts: Total leucocytes count (TLC) was done following standard haematological techniques using haemocytometer. A thin smear was drawn from each blood sample on grease free glass slide, fixed in methanol and stained for 40 minutes in Giemsa solution and observed under microscope using oil immersion (100X) objective. The proportion of neutrophils, lymphocytes and band cells were recorded.

\section{Neutrophil functions assay}

Respiratory burst activity of neutrophil was adjudged on the basis of superoxide and hydrogen peroxide production ability in collected blood samples. Neutrophils were separated from $10 \mathrm{~mL}$ blood by hypotonic lysis of RBC (Carlson and Kaneko, 1973). Viability of separated neutrophil was determined by 0.1 per cent Trypan blue dye exclusion technique (Colligan et al., 1994). The concentrations of total viable cells were calculated and the final concentration was adjusted to $10 \times 10^{6}$ cells $/ \mathrm{mL}$ in isotonic PBS.

Superoxide production assay: Superoxide production of neutrophil was measured by nitroblue tetrazolium (NBT) reduction assay following the method described by Nagahata et al. (1986). In a test tube $200 \mu \mathrm{L}$ of NBT solution ( $0.1 \%$ NBT in Earle's solution), $200 \mu \mathrm{L}$ of $10 \times 10^{6}$ 
cell suspension and $25 \mu \mathrm{g} \quad(1 \mu \mathrm{g} / \mu \mathrm{L})$ of $E$. coli lipopolysaccharide (LPS, Sigma Aldrich) were taken and the final volume was made $440 \mu \mathrm{L}$ by adding $15 \mu \mathrm{L}$ of Earle's solution. Duplicate sample was prepared in another test tube by adding all components except LPS considering as resting sample and incubated for $30 \mathrm{~min}$. The difference of OD $(\triangle \mathrm{OD})$ was calculated by subtracting the OD of resting sample from the OD of sample stimulated by LPS. The superoxide production result was expressed as $\Delta \mathrm{OD} / 10 \times 10^{6}$ neutrophil/30 min.

Hydrogen production assay: Hydrogen peroxide production of neutrophil was assessed based on the horseradish peroxidase (HRPO) mediated oxidation of phenol red that resulted in formation of a compound demonstrating increase absorbance at $610 \mathrm{~nm}$ (Pick and Keisari, 1980). The $\mathrm{H}_{2} \mathrm{O}_{2}$ production was estimated by plotting the absorbance of test samples in a standard curve. The standard curve was drawn using the absorbance of $\mathrm{H}_{2} \mathrm{O}_{2}$ solution at concentration $1 \mu \mathrm{M}, 10 \mu \mathrm{M}, 20 \mu \mathrm{M}, 30$ $\mu \mathrm{M}$ and $50 \mu \mathrm{M}$ concentration (Figure 1). The concentration of $\mathrm{H}_{2} \mathrm{O}_{2}$ in test samples were calculated using the regression equation $\mathrm{Y}=0.01 \mathrm{X}+0.033, \mathrm{X}=$ concentration, $\mathrm{Y}=$ absorbance, $\mathrm{R}^{2}=0.998$. The result was expressed as $\mu \mathrm{M}$ of $\mathrm{H}_{2} \mathrm{O}_{2} / 10 \times 10^{6}$ Neutrophils.

\section{Expression profile of cytokines in PBMCs of buffaloes during periparturient period}

The relative mRNA expression profile of cytokines viz., IL-2, IFN- $\gamma$ and IL-4 in peripheral blood mononuclear cells (PBMCs) were studied by Real-time reverse transcriptase PCR. The PBMCs were isolated by density gradient centrifugation using Lymphocyte Separation Media (LSM, density $1.077 \pm 0.001$, Eurobio). The cell suspension was cultured for $48 \mathrm{~h}$ in $37^{\circ} \mathrm{C}$ at $\mathrm{CO}_{2}$ environment in a six well microplate at $2 \times 10^{6}$ cells $/ \mathrm{mL}$ concentration and E. coli LPS (Sigma Aldrich) was supplemented at $1 \mu \mathrm{g} / \mathrm{mL}$ for induction of cytokine expression. Total RNA was extracted from the PBMCs using Trizol (Ambion). The quantity and quality of total RNA was checked by measuring the optical density of the RNA sample solution at 260 and $280 \mathrm{~nm}$ at

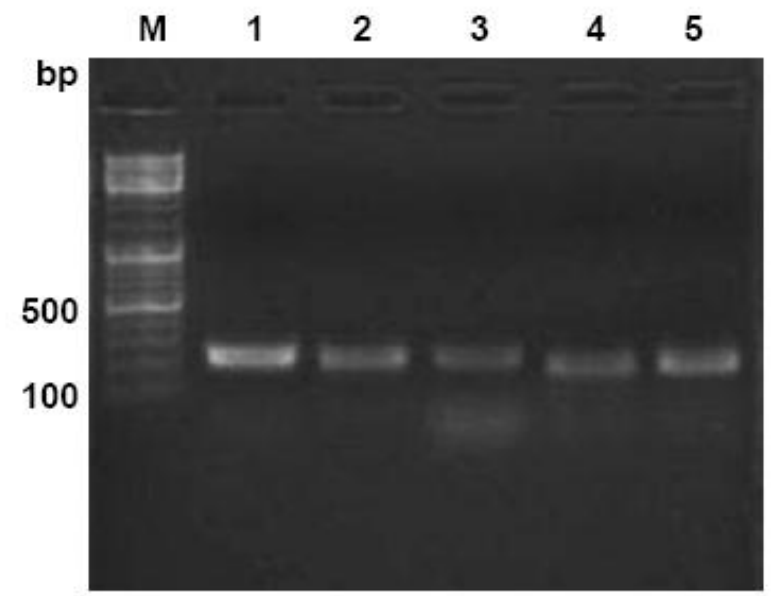

Figure 1. Agarose gel $1.5 \%$ (w/v) electrophoresis of PCR products. Lane M: 100 bp DNA ladder, Lane 1: $\beta$-actin (227 bp), Lane 2: IFN- $\beta$ (218 bp), Lane 3: IL-2 (217 bp), Lane 4-5: IL-4 (197 bp).

nanodrop spectrophotometer. The extracted total RNA (2 $\mu \mathrm{g}$ ) was reverse-transcribed using RevertAid M-MuLV Reverse Transcriptase enzyme (Fermentas) and oligo (dT) ${ }_{18}$ primer (Fermentas) to synthesize the complimentary DNA (cDNA) following manufacturers' instructions using a negative control. The reaction mixture was prepared using RNA template, $1 \mu \mathrm{L}(0.5 \mu \mathrm{g})$ Oligo (dT) primer, $4 \mu \mathrm{L}$ RT $5 \times$ buffer, $2 \mu \mathrm{L}$ of $10 \mathrm{mM}$ dNTPs, $1 \mu \mathrm{L}(20 \mathrm{U})$ RNAse inhibitor, $1 \mu \mathrm{L}(200 \mathrm{U})$ of RT enzyme and DEPC water upto $20 \mu \mathrm{L}$.

Both forward and reverse primers for each target genes (IL-2, IFN- $\gamma$ and IL-4) including house-keeping gene ( $\beta$-actin) were designed using online primer3 software (http://frodo.wi.mit.edu/cgi-bin/primer3/primer3_www.cgi) from the published complete or partial gene sequences available with the National Centre for Biotechnology Information. The oligonucleotide primer sets (20 base pair) were custom synthesized by Bioserve, Hyderabad, India (Table 1). The PCR cyclic condition was standardized for target and house-keeping genes by using different concentration of Magnesium chloride and annealing

Table 1. List of primers used for amplification of cytokine genes in peripheral blood mononuclear cells of buffaloes that did and did not develop postpartum reproductive disorders (PRD)

\begin{tabular}{|c|c|c|c|c|c|}
\hline Sl. No. & Target gene & Primer sequence & $\begin{array}{l}\text { Product size } \\
\quad \text { (bp) }\end{array}$ & Acc No. & $\begin{array}{c}\text { Annealing } \\
\text { temperature }\left({ }^{\circ} \mathrm{C}\right)\end{array}$ \\
\hline 1 & $\beta$-actin & $\begin{array}{l}\text { F 5'-CGC ACC ACT GGC ATT GTC AT-3' } \\
\text { R 5'-TCC AAG GCG ACG TAG CAG AG-3' }\end{array}$ & 227 & K00662 & 55 \\
\hline 2 & IL-2 & $\begin{array}{l}\text { F 5'-TTT TAC GTG CCC AAG GTT AA-3' } \\
\text { R 5'-CGT TTA CTG TTG CAT CAT CA-3' }\end{array}$ & 217 & M12791 & 54 \\
\hline 3 & IFN- $\gamma$ & $\begin{array}{l}\text { F 5'-ATA ACC AGG TCA TTC AAA GG-3' } \\
\text { R 5'-ATT CTG ACT TCT CTT CCG CT-3' }\end{array}$ & 218 & M29867 & 55 \\
\hline 4 & IL-4 & $\begin{array}{l}\text { F 5'-GTA CCA GTC ACT TCG TCC AT-3', } \\
\text { R 5'-GCT CCT GTA GAT ACG CCT AA-3' }\end{array}$ & 197 & AY293620.1 & 52 \\
\hline
\end{tabular}


temperatures. The reaction mixture was prepared comprising of $2.5 \mu \mathrm{L}$ Taq polymerase buffer $(10 \times), 1.5 \mu \mathrm{L}$ Magnesium chloride $(15 \mathrm{mM}), 0.5 \mu \mathrm{L}$ of each forward and reverse primer $(10 \mathrm{pmol} / \mu \mathrm{L}), 0.5 \mu \mathrm{L}$ dNTPs mixture $(10$ $\mathrm{mM})$ each, $1 \mu \mathrm{L}$ Taq polymerase recombinant, LC $(1 \mathrm{U} / \mu \mathrm{L}$, Fermentas), $1 \mu \mathrm{L}$ Template cDNA and nuclease free water up to $25 \mu \mathrm{L}$ in a thermal cycler (Gene Amp PCR System9700, Applied Bio System). The initial denaturation was done at $94^{\circ} \mathrm{C}$ for $5 \mathrm{~min}$ followed by 30 cycles of cyclic denaturation at $94^{\circ} \mathrm{C}$ for $30 \mathrm{~s}$, annealing at temperature specified in Table 1 , for $30 \mathrm{~s}$ and extension at $72^{\circ} \mathrm{C}$ for $30 \mathrm{~s}$ followed by final extension at $72^{\circ} \mathrm{C}$ for $5 \mathrm{~min}$. The amplified PCR products were checked by electrophoresis in $1.5 \%$ agarose gel in $1 \mathrm{X}$ TAE buffer using known 100 bp ready to use DNA ladder (Fermentas, Figure 1).

Further, the target genes and house-keeping gene were amplified in Real-time PCR system (MX-3000P spectrofluorometric thermal cycler, Stratagene). The PCR master mix (2X) provided with the Maxima SYBR Green qPCR kit (Fermentas Life Science) was used for Real-time PCR. The cyclic condition used in Real-time PCR system was consisted of one cycle of initial denaturation at $95^{\circ} \mathrm{C}$ for $10 \mathrm{~min}$ followed by 40 cycles of cyclic denaturation at $95^{\circ} \mathrm{C}$ for $15 \mathrm{~s}$, annealing for $30 \mathrm{~s}$ at temperature specified in Table 1 and extension at $72^{\circ} \mathrm{C}$ for $30 \mathrm{~s}$. The dissociation curve underwent a cycle consisted of $95^{\circ} \mathrm{C}$ for $1 \mathrm{~min}$ followed by $55^{\circ} \mathrm{C}$ for $30 \mathrm{~s}$ and gradual increase in temperature at $1^{\circ} \mathrm{C}$ at $30 \mathrm{~s}$ from $55^{\circ} \mathrm{C}$ to $95^{\circ} \mathrm{C}$ and finally at $95^{\circ} \mathrm{C}$ for $1 \mathrm{~min}$. The fluorescent data acquisition was recorded at the end of each extension step and continuously from $55^{\circ} \mathrm{C}$ to $95^{\circ} \mathrm{C}$ during the dissociation curve analysis step. The threshold cycle value for each target (IL-2, IL-4 and IFN- $\gamma$ ) and house-keeping genes were recorded for evaluation of fold of expression and the dissociation curve for each amplified product of the target genes were examined to verify the specificity of the product. The relative fold change of target genes (IL-2, IFN- $\gamma$ and IL-4) in PBMC of buffaloes from one week pre-calving to four weeks post-calving period at weekly interval was determined by the relative quantification method $\left(2^{-\Delta \Delta C t}\right)$ described by Livak and Schmittgen (2001) using $\beta$-actin as endogenous control and day of calving as calibrator.

\section{Statistical analysis}

All the data were analyzed using statistical package SPSS 16.0. The data obtained from leucocytes count, neutrophil functions were analyzed by independent t-test for comparison of mean values between two groups. Effect of sampling time on blood leucocytes and neutrophil functions was analyzed by one way ANOVA with Duncun multiple range test (DMRT) as post hock analysis.

The $\mathrm{Ct}$ values of $\beta$-actin genes for healthy control and buffaloes with PRD were analyzed by Shapiro-Wilk test and the test of significance was adjudged based on independent t-test. The data related to fold expression $\left(2^{-\Delta \Delta C t}\right)$ of cytokines genes were not normally distributed, the statistical analysis was performed on the $\Delta \Delta \mathrm{Ct}$ values using independent t-test and then converted to $2^{-\Delta \Delta \mathrm{Ct}}$ for data presentation. The cytokines expression at different time points within each group was compared using one way ANOVA with DMRT as post hock analysis. The difference of mean values for all data analyzed with $\mathrm{p}<0.05$ was considered as significant, whereas $0.05<p<0.10$ was considered as tendency.

\section{RESULTS}

\section{Periparturient changes in total leucocytes and neutrophil counts}

The periparturient blood leucocytes profile in buffaloes with postpartum reproductive disorder (group II) and healthy buffaloes (group I) is presented in Figure 2a-d. A significantly lower $(\mathrm{p}<0.05)$ TLC $(8.53 \pm 0.74)$ was observed in PRD group at one week before calving that rebounded to similar level as observed in healthy group at one week after calving. However, a significant increase in TLC was noted in buffaloes with PRD as compared to healthy at 3rd $(12.82 \pm 1.03)$ and 4 th $(13.25 \pm 1.01)$ week postpartum, respectively. The mean neutrophils count in group II was comparatively higher than group I at prepartum $(34.16 \pm 3.56$ vs $23.95 \pm 0.93$ ), and tended to be significant during calving and 4 weeks post calving period. However, distinct 'shift to left' was observed in immature neutrophils count (Band cells) during the periparturient period in buffaloes with PRD. The proportion of band cells was significantly higher $(\mathrm{p}<0.05)$ at prepartum $(10.16 \pm 2.05$ vs $3.87 \pm 0.59)$, during calving $(15.56 \pm 1.30$ vs $7.68 \pm 1.53)$ and 4 wks after calving (13.54 \pm 3.64 vs $5.03 \pm 1.64)$ in buffaloes with PRD as compared to healthy. The lymphocytes count was also significantly higher $(\mathrm{p}<0.05)$ in healthy as compared to PRD buffaloes at day of calving $(56.98 \pm 2.85$ vs $47.10 \pm$ 2.42), and tended to be higher on 1 st and 4 th week following calving. Moreover, the lymphocytes proportion tended to increase from prepartum to postpartum period in healthy group, however, no definite trend was observed in buffaloes with PRD.

\section{Neutrophil function}

The superoxide production $\left(\Delta \mathrm{OD} / 10 \times 10^{6}\right.$ neutrophils/ $30 \mathrm{~min})$ of neutrophils was significantly $(\mathrm{p}<0.05)$ lower particularly at prepartum and day of calving in buffaloes with PRD than healthy (Figure 3a). The superoxide production was gradually decreased in healthy buffaloes (group I) from a higher prepartum level $(0.560 \pm 0.02)$ up to 


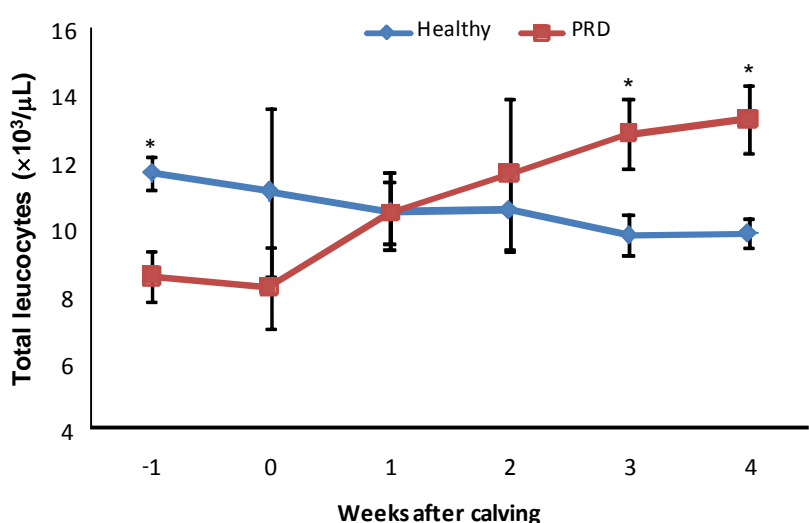

(a)

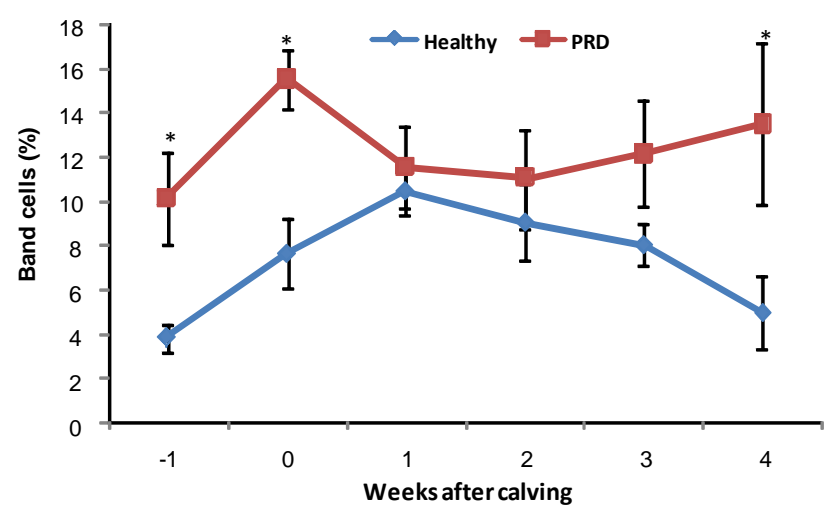

(c)

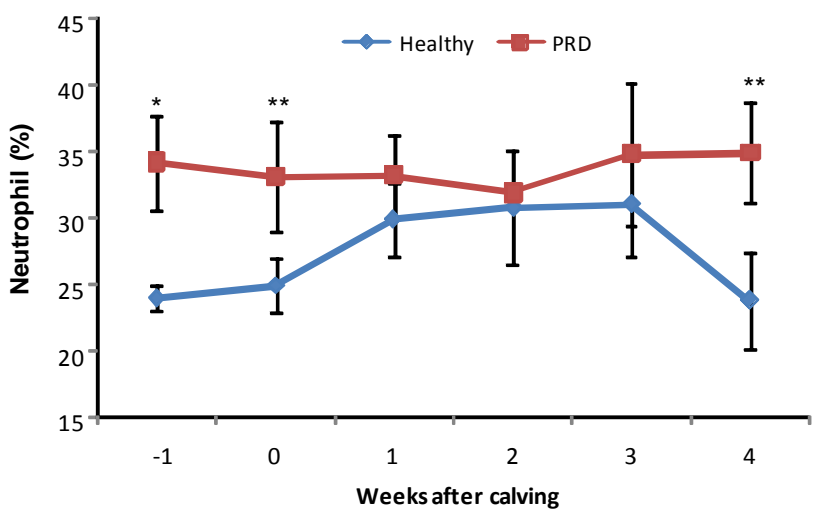

(b)

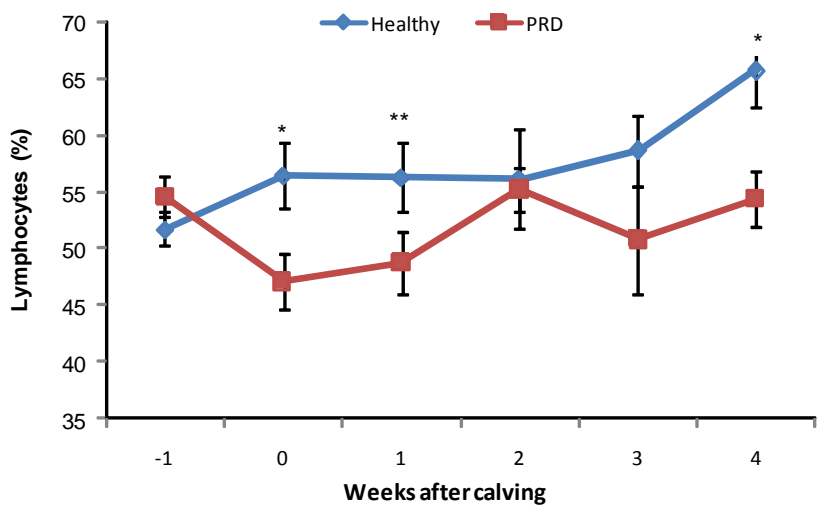

(d)

Figure 2. Total leucocytes count $\left(\times 10^{3} / \mu \mathrm{L}\right.$ of blood) (a), neutrophil (b), band cells (c) and lymphocytes (d) count (\%) in peripheral blood of buffaloes that did $(n=8)$ and did not $(n=6)$ develop postpartum reproductive disorders (PRD). Values are shown as mean \pm SEM, $*$ indicates significant difference between the groups $(\mathrm{p}<0.05)$; ** indicates tendency towards significant difference between groups $(\mathrm{p}<0.10)$.

2nd wk postpartum $(0.297 \pm 0.049)$ however, the superoxide production remained lower in buffaloes that developed PRD (group II) all over the sampling days. The hydrogen peroxide $\left(\mathrm{H}_{2} \mathrm{O}_{2}\right)$ production assay of neutrophils revealed a significantly lower production in PRD than healthy buffaloes at prepartum and 2 nd wk postpartum period respectively (Figure 3b). Moreover, the $\mathrm{H}_{2} \mathrm{O}_{2}$ production in PRD buffaloes was gradually increased from a lowest level $(10.49 \pm 1.20 \mu \mathrm{M})$ at prepartum to $32.62 \pm 2.55 \mu \mathrm{M}$ at 4 th week postpartum. However, in the healthy buffaloes the $\mathrm{H}_{2} \mathrm{O}_{2}$ production was found to be the highest (48.84 \pm 11.39 $\mu \mathrm{M})$ during 2 nd wk postpartum and significantly greater $(p<0.05)$ than the day of calving.

\section{Cytokine expression in PBMCs culture}

The relative mRNA expression of IL-2, IFN- $\gamma$ and IL-4 in PBMCs of buffaloes with and without PRD was determined by RT-PCR. The mRNA expression of housekeeping gene ( $\beta$-actin) was consistent and there was no significant difference observed in $\mathrm{Ct}$ values between the buffaloes with and without PRD ( $\mathrm{p}>0.05)$ with average $\mathrm{Ct}$ value $22.46 \pm 0.62$ and $21.43 \pm 0.51$, respectively. The mRNA expression of IL-2 before parturition had a tendency to be lower than those after parturition. This tendency was observed in both healthy and PRD buffaloes (Figure 4a). A significantly higher expression of IL-2 was observed in healthy buffaloes at 2 nd wk $(1.53$ vs 0.32 fold, $\mathrm{p}<0.05)$ and tended to be higher on 4 th wk postpartum in comparison to PRD buffaloes, though this elevated expression was elicited during all the days postpartum in healthy group. Moreover, the fold changes of IL-2 expression in group I buffaloes did not differ during the course of periparturient period, whereas, the expression of IL-2 was significantly upregulated from prepartum to day of calving $(\mathrm{p}<0.05)$, and declined gradually during the postpartum period in the buffaloes with PRD.

Overall, from calving to $3 \mathrm{rd}$ wk the expression of IFN- $\gamma$ tended to be greater in buffaloes without PRD than with PRD (Figure 4b). The relative expression of IFN- $\gamma$ in healthy group was increased gradually since prepartum (0.56 fold) up to 2 nd wk (2.89 fold) of postpartum and subsequently declined in 3rd (0.73 fold) and 4th wk $(0.70$ fold). However, in PRD buffaloes the expression pattern was almost similar in all the time points except at $3 \mathrm{rd} \mathrm{wk}$ 


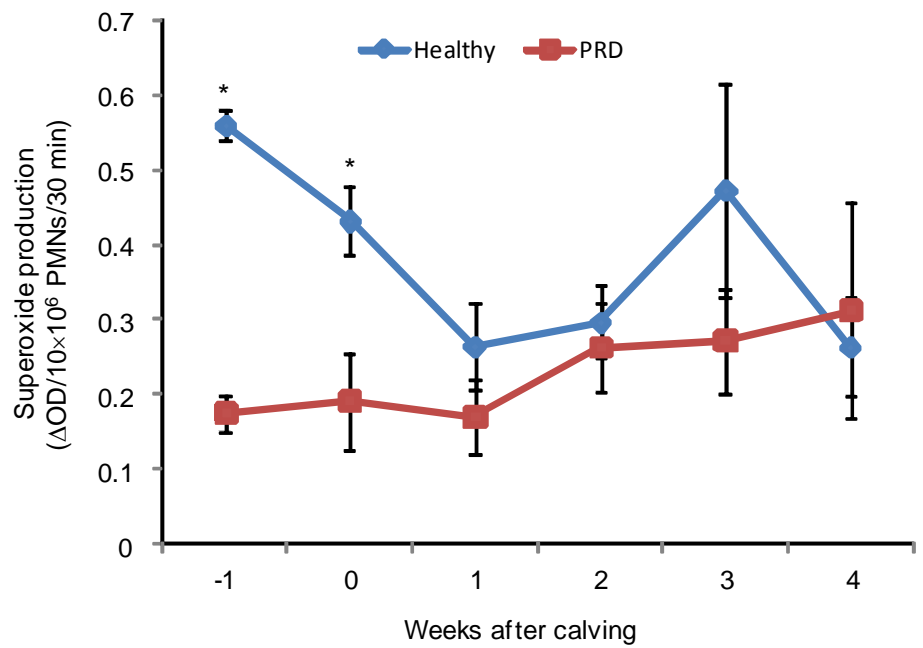

(a)

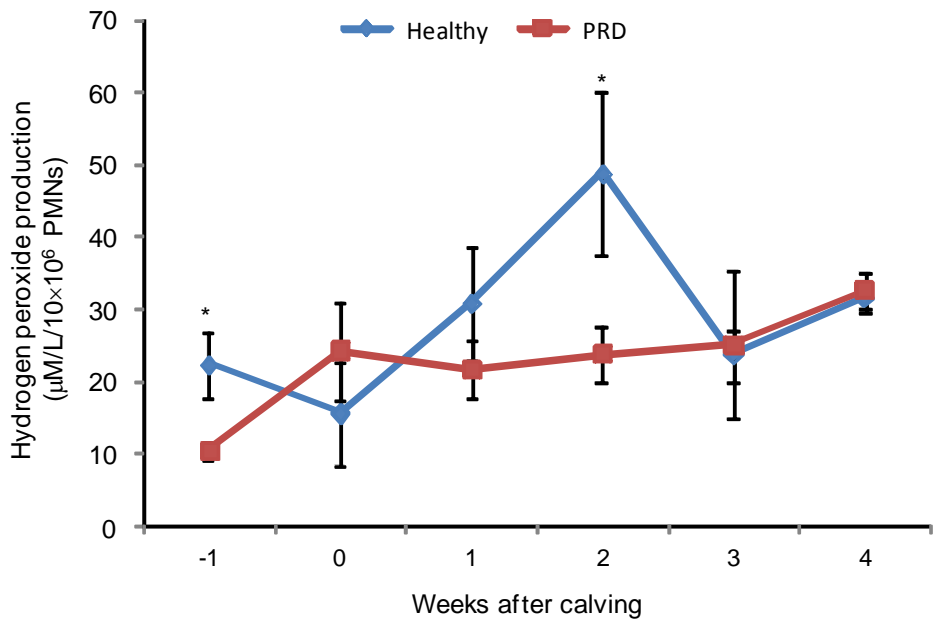

(b)

Figure 3. Superoxide production $\left(\Delta \mathrm{OD} / 10 \times 10^{6}\right.$ Neutrophils $\left./ 30 \mathrm{~min}\right)(\mathrm{a})$, hydrogen peroxide production $\left(\mu \mathrm{M} / 10 \times 10^{6}\right.$ neutrophils $)(\mathrm{b})$ profile in buffaloes that did $(\mathrm{n}=8)$ and did not $(\mathrm{n}=6)$ develop postpartum reproductive disorder $(\mathrm{PRD})$. Values are shown as mean $\pm \mathrm{SEM}, *$ indicates significant difference between the groups $(\mathrm{p}<0.05)$.

postpartum (0.67 fold) where the mean fold was significantly lower $(\mathrm{p}<0.05)$. The mean fold change of IL-4 cytokine mRNA was tended to be higher throughout the periparturient period in healthy buffaloes as compared to buffaloes with PRD (Figure 4c) and the expression was significantly greater $(\mathrm{p}<0.05)$ during $1 \mathrm{st} w \mathrm{w}, 2 \mathrm{nd} w \mathrm{wk}$ and 4 th wk. Comparison of mean fold changes of IL-4 expression in healthy buffaloes relative to weeks of calving did not reveal any significant difference $(\mathrm{p}>0.10)$, however, in the buffaloes with PRD, the expression pattern was found to be significantly higher on day of calving (1.36 fold) as compared to prepartum, $1 \mathrm{st} w \mathrm{w}$, 3rd wk and 4th wk of postpartum $(\mathrm{p}<0.05)$.

\section{DISCUSSION}

Determining the immune status of periparturient animals in relation to the occurrence of endometritis, metritis and delayed uterine involution (PRD) during the postpartum period may assist to develop some efficient reproductive management strategies for dairy animals. In this study the buffaloes that developed PRD were associated with an increase TLC, neutrophils count, accompanied by an increase in immature band cells. The rise in TLC above the normal physiological limit at prepartum and during calving in healthy buffaloes, in fact may be associated with reduced glucocorticoid receptor (GR) expression in blood neutrophils and antepartum rise in cortisol level leading to neutrophilia and leucocytosis as suggested by Preisler et al. (2000). The glucocorticoid receptors are involved in periparturient immunosuppression caused by impaired expression of adhesion molecules and decreased migration capacity of blood neutrophils. Altered gene transcription mediated by glucocorticoid- bound GR could explain reduced expression of certain plasma membrane proteins on neutrophils, such as CD62L that is severely down-regulated 


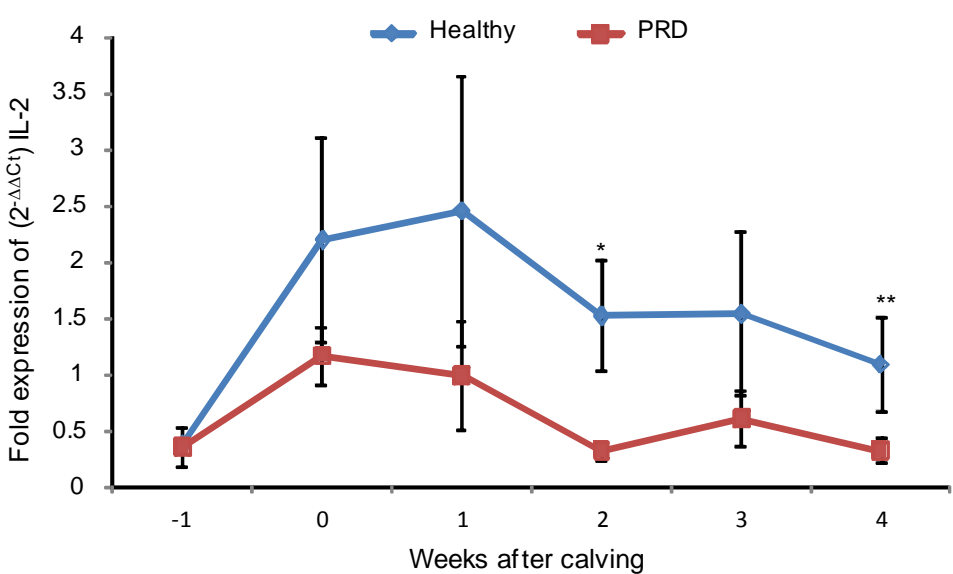

(a)

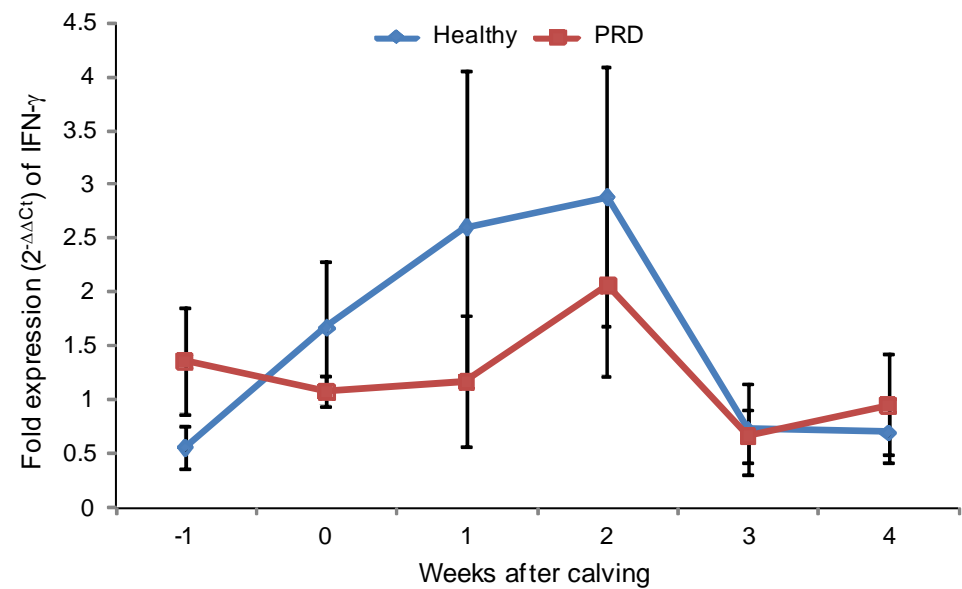

(b)

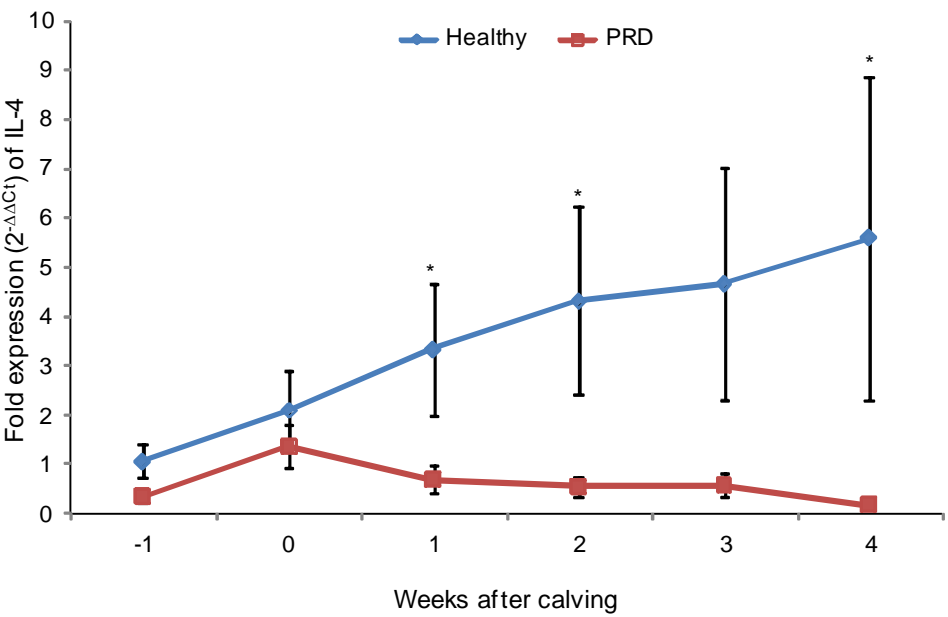

(c)

Figure 4. Fold change $\left(2^{-\Delta \Delta C t}\right)$ of IL-2 (a), IFN- $\gamma(b)$, IL- 4 (c) relative to day of calving in buffaloes that did $(n=8)$ and did not $(n=6)$ develop postpartum reproductive disorders (PRD). Values are shown as mean \pm SEM, * indicates significant difference between the groups $(\mathrm{p}<0.05), * *$ indicates tendency towards significant difference $(\mathrm{p}<0.10)$.

in cows at parturition (Lee and Kehrli, 1998). This could be the cause of leukocytosis and neutrophilia that has been reported in other studies of periparturient dairy cows (Cai et al., 1994) that strongly implicates cortisol activation of neutrophil GR as a mechanism that causes neutrophilia.
Subsequently the normal decline in leucocytes count observed in buffaloes that did not develop PRD in later postpartum period might be due to the migration of the leucocytes towards the uterine lumen and mammary gland. The buffaloes with PRD had significantly lower TLC at 
prepartum, but higher count at subsequent weeks of postpartum indicates the inflammatory status in these buffaloes. This could be explained by the findings of Ohtsuka et al. (2004), who reported that the animals with reproductive disease or mastitis showed a prolonged increase in plasma cortisol that can inhibit translocation of transcription factor, and induce variable immunosuppression. The immunosuppressive effect of cortisol and metabolic adjustment at the transition period of pregnancy to lactation (Holtenius et al., 2004) are suspected to be the predisposing agents of immunosuppression in buffaloes that developed PRD in this experiment.

The finding of increase in neutrophils count, accompanied by rise in immature band cells in buffaloes impending PRD is supported by Mateus et al. (2002) who also reported the immature neutrophils in the range of 5 to $15 \%$ in cows with endometritis at periparturient period. An important finding in present study was that the total neutrophils and band cells count in buffaloes with PRD were higher before calving than the healthy buffaloes. This suggests that the PRD buffaloes might be already in stress condition in some way other than infection. Thus, it may be speculated that this preexisting stress condition caused immunosuppression during periparturient period and predisposes the buffaloes to develop PRD.

A reduced respiratory burst activity was elicited in terms of superoxide and $\mathrm{H}_{2} \mathrm{O}_{2}$ production at different sampling points during the periparturient period in buffaloes that developed PRD. The significant lower superoxide and $\mathrm{H}_{2} \mathrm{O}_{2}$ production during one week prepartum in buffaloes that developed PRD indicated attenuated respiratory burst activity of neutrophils. This attenuation may be associated with increase immature neutrophils in circulation. The immature neutrophils (band cells) in circulation possess substantially lower oxygen dependent respiratory burst activity than mature neutrophils (Detilleux et al., 1995). The preterm attenuation of neutrophils functions in cows that developed postpartum metritis was also observed by Cai et al. (1994) and this initiation of functional defect possibly acts as predisposing factor in development of subsequent PRD.

The healthy buffaloes showed the higher superoxide production at prepartum i.e., greater neutrophil functions indicating no inflammatory signs as suggested by Piccinini et al. (2004). The gradual decline in superoxide production by neutrophils during pre- to post calving period might be due to the influences of physiological changes in major steroid hormone level and greater degree of negative energy balance (Hammon et al., 2006; Galvão et al., 2010). The gradual increase in superoxide production from second week postpartum and $\mathrm{H}_{2} \mathrm{O}_{2}$ production since first week postpartum indicate a physiological recovery of neutrophils function in buffaloes that did not develop PRD. This contention receives supports from the findings of Mateus et al. (2002) who also observed a decrease in neutrophils oxidative burst activity until the first week postpartum that could be associated with susceptibility to early postpartum endometritis and later gradual increase in respiratory burst activity may favor spontaneous resolution.

The decreased lymphocytes count along with reduced functional ability during periparturient period in buffaloes that developed PRD is in accordance with the results of earlier works (Holtenius et al., 2004; Ohtsuka et al., 2004). A lymphopenia like condition in animal with periparturient inflammatory diseases may be associated with corticosteroid induced shifts of lymphocytes from blood to other body compartments or due to lympholysis, especially of T cells as suggested by Jain (1993). In contrary, Kim et al. (2005) reported increase in lymphocytes count during periparturient period in endometritic cows.

The development of reproductive disorders during the course of periparturient period depends on the general immune status of animals. This study demonstrated for the first time the relative expression profile of IL-2, IFN- $\gamma$ and IL-4 in PBMCs in buffaloes with and without postpartum reproductive disorders. The lower levels of IL-2 and IFN- $\gamma$ expression by PBMCs in buffaloes that developed postpartum complications is similar to the expression of IL-2 mRNA in PBMCs during periparturient period with the development of infectious diseases observed by Sato (1998). In earlier study they correlated the suppression of lymphocyte blastogenesis with higher incidence of postpartum metritis in cows (Sato et al., 1995). The immunosuppression during periparturient period in cows is also suggested to be related with the occurrence of mastitis and postpartum metritis (Mallard et al., 1998). Similarly, Sukhikh et al. (2005) also observed lower proportion of IFN- $\gamma$ synthesizing $\mathrm{Th}_{1}$ cells in patients with moderate to severe endometritis as compared to healthy women at postpartum period. Several mechanisms for immunosuppression have been advocated at the time of parturition. High circulating level of estradiol and corticosteroids can suppress important lymphocyte functions. Lower proportions of $\mathrm{T}$ lymphocytes and decrease $\mathrm{CD} 2^{+}, \mathrm{CD}^{+}$and $\mathrm{CD} 8^{+}$subsets of $\mathrm{T}$ lymphocytes are reported in peripheral blood of cows (Shafer-Weaver and Sordillo, 1996). They also explained that reduced secretion of IL- 2 and IFN- $\gamma$ (products of $\mathrm{Th}_{1} \mathrm{CD}^{+}$cells) during the postpartum period was correlated with the higher incidence of mastitis in cows.

Further, as observed by Shafer-Weaver et al. (1999) that the Th- $2 \mathrm{CD}^{+}$T-lymphocytes mainly secretes IL-4 and other anti-inflammatory cytokines, promoter of humoral immunity and we observed a decrease tendency of IL-4 
expression in buffaloes that developed postpartum reproductive disorders, it is reasonable to suggest that during the periparturient period the host immunity might have diminished in our experimental buffaloes those developed postpartum complications. This contention receives indirect evidence from Choma et al. (2000) who observed a lower antibody titre in dairy cows immunized with ovo-albumen, suffering from postpartum complications as compared with higher antibody titre in healthy cows. Thus, these results also confirm the immunosuppressive role of IL-4 cytokine during the periparturient period.

The present results show a decrease in the cellular functions regulated by $\mathrm{T}$ lymphocytes that may be probable reason for rendering the buffaloes more susceptible to diseases. Though, we have not examined the subpopulation of $\mathrm{T}\left(\mathrm{CD} 2^{+}, \mathrm{CD}^{+}\right.$and $\left.\mathrm{CD}^{+}\right)$cells in this experiment but our results of lower expression of IL-2, IFN- $\gamma$ and IL-4 and significant decrease in lymphocyte absolute numbers reflected as lymphocyte trafficking. Further, impaired neutrophil cell functions certainly indicate immunosuppression in buffaloes those developed postpartum reproductive disorders in this study. However, studies with larger number of animals and higher frequencies of postpartum complications would be needed to confirm these observations.

\section{CONCLUSIONS}

From this experiment it can be concluded that the impaired neutrophils function in terms of lowered production of superoxide and $\mathrm{H}_{2} \mathrm{O}_{2}$ before parturition and during postpartum period may predispose the buffaloes to develop reproductive disorders. Further, higher total leucocytes, neutrophil and band cells count in the buffaloes with PRD may be due to the prevailing uterine infections in postpartum period. Moreover, a lower level of expression in IL-2, IFN- $\gamma$ and IL-4 mRNA in PBMCs at calving might impair activation of inflammation and clearance of microbes and lead to development of postpartum reproductive disorders. Thus, a thorough understanding of immune functional mechanism at periparturient period will be beneficial for prediction of impending reproductive disorders at postpartum period.

\section{ACKNOWLEDGEMENT}

The author is grateful to the Director, Indian Veterinary Research Institute (Indian Council of Agri. Research, New Delhi) for extending the facility to carry out the research work. The study was partly funded by the Institute plan project.

\section{REFERENCES}

Cai, T. Q., P. G. Weston, L. A. Lung, B. Brodie, D. J. Mekenna, and W. C. Wagner. 1994. Association between neutrophil functions and periparturient disorders in cows. Am. J. Vet. Res. 55:934-943.

Carlson, G. and J. J. Kaneko. 1973. Isolation of leucocytes from bovine peripheral blood. Proc. Soc. Exp. Biol. Med. 142:853856.

Carter, L. L. and R. W. Dutton. 1996. Type 1 and type 2: a fundamental dichotomy for all T-cell subsets. Curr. Opin. Immunol. 8:336-342.

Chapwanya, A. 2008. Uterine disease in dairy cows: classification, diagnosis and key roles for Veterinarians. Irish Vet. J. 61:183185

Choma, J., P. Nad, V. David, and M. Biresov. 2000. The observation of antibody production during puerperium in dairy cows. Folia Vet. 44:204-205.

Colligan, J. E., A. M. Kruibeek, D. H. Marguhes, E. M. Shevach, and W. Strober. 1994. Current protocols in immunology. In: Current Protocols, Vol. 2. USA. pp. A3.1 to A3.3.

Custer, E. E., J. G. Berardinelli, R. E. Short, M. Wehrman, and R. Adair. 1990. Postpartum interval to estrus and patterns of LH and progesterone in first- calf suckled beef cows exposed to mature males. J. Anim. Sci. 68:1370-1377.

Detilleux, J. C., Jr. M. E. Kehrli, J. R. Stabel, A. E. Freeman, and D. H. Kelley. 1995. Study of immunological dysfunction in periparturient Holstein cattle selected for high and average milk production. Vet. Immunol. Immunopathol. 44:251-267.

Galvão, K.N., M. J. B. F. Flaminio, S. Z. Brittin, R. Sper, M. Fraga, L.Caixeta, A. Ricci, C. L. Guard, W. R. Butler, and R. O. Gilbert. 2010. Association between uterine disease and indicators of neutrophil and systemic energy status in lactating Holstein cows. J. Dairy Sci. 93:2926-2937.

Hagiwara, E., F. Abbasi, G. Mor, Y. Ishigatsubo, and D. M. Klinman. 1995. Phenotype and frequency of cells secreting IL2 , IL-4, IL-6, IL-10, IFN- $\gamma$, and TNF- $\alpha$ in human peripheral blood. Cytokine 7:815-822.

Hammon, D. S., I. M. Evjen, T. R. Dhiman, J. P. Goff, and J. L. Walters. 2006. Neutrophil function and energy status in Holstein cows with uterine health disorders. Vet. Immunol. Immunopathol. 113:21-29.

Hoedemaker, M., L. A. Lund, and W. C. Wagner. 1992. Influence of arachidonic acid metabolites and steroids on function of bovine polymorphonuclear neutrophils. Am. J. Vet. Res. 53: 1534-1543.

Holtenius, K., K. Persson- Waller, B. Essen-Gustavsson, P. Holtenius, and C. Hallen Sandgren. 2004. Metabolic parameters and blood leukocyte profiles in cows from herds with high and low mastitis incidence. Vet. J. 168:65-73.

Hussain, A. M. 1989. Bovine uterine defense mechanisms: a review. J. Vet. Med. Series B. 36:641-651.

Hussain, A. M. and R. C. W. Daniel. 1992. Phagocytosis by uterine fluid and blood neutrophils and hematological changes in postpartum cows following normal and abnormal parturition. Theriogenology 37:1253-1267.

Ishikawa, H., T. Shirahata, and K. Hasegawa. 1994. Interferon gamma production of mitogen stimulated peripheral lymphocytes in perinatal cows. J. Vet. Med. Sci. 56:735-738. 
Jain, N. C. 1993. The lymphocytes and plasma cells. In: Essentials in Veterinary Haematology (Ed. N. C. Jain). Lea and Fabiger, Philadelphia, USA.

Kim, I. H., K. J. Na, and M. P. Yang. 2005. Immune response during the postpartum period in dairy cows with postpartum endometritis. J. Reprod. Dev. 51:757-764.

Lee, E-K. and M. E. Jr. Kehrli. 1998. Expression of adhesion molecules on neutrophils of periparturient cows and neonatal calves. Am. J. Vet. Res. 59:37-43.

Lewis, G. S. 1997. Uterine health and disorders. J. Dairy Sci. 80: 984-994.

Livak, K. J. and T. D. Schmittgen. 2001. Analysis of relative gene expression data using real-time quantitative PCR and the 2(Delta Delta C(T)) method. Methods 25:402-408.

Mallard, B. A., J. C. Dekkers, M. J. Ireland, K. E. Leslie, S. Sharif, C. L. Vankampen, L. Wagter, and B. N. Wilkie. 1998. Alteration in immune responsiveness during the peripartum period and its ramification on dairy cow and calf health. J. Dairy Sci. 81:585-595.

Mateus, L., L. Lope de Costa, H. Carvalho, P. Serra, and J. Robalo Silvia. 2002. Blood and intrauterine leucocyte profile and function in dairy cows that spontaneously recovered from postpartum endometritis. Reprod. Domest. Anim. 37:176-180.

Nagahata, H., A. Yatsu, and H. Noda. 1986. The evaluation of a quantitative assay for estimating the bactericidal activity of bovine neutrophils by nitroblue tetrazolium reduction. Br. Vet. J. 142:578-584

Ohtsuka, H., M. Koiwa, S. Fukuda, Y. Satosh, T. Hayashi, F. Hoshi, T. Yoshino, and S. Kawamura. 2004. Changes in peripheral leucocyte subsets in dairy cows with inflammatory diseases after calving. J. Vet. Med. Sci. 66:905-909.

Piccinini, R., E. Binda, M. Belotti, G. Casirani, and A. Zecconi. 2004. The evaluation of non-specific immune status of heifers in field conditions during the periparturient period. Vet. Res. 35:539-550.

Pick, E. and Y. Keisari. 1980. A simple colorimetric method for the measurement of hydrogen peroxide produced by cells in culture. J. Immunol. Meth. 38:161-170.
Preisler, M. T., P. S. Weber, R. J. Tempelman, R. J. Erskine, H. Hunt, and J. L. Burton. 2000. Glucocorticoid receptor downregulation in neutrophils of periparturient cows. Am. J. Vet. Res. 61:14-19.

Sato, S. 1998. Immunosuppression in periparturient cows and the effects of immunostimulation. Tohoku J. Vet. Clin. 21:61-70.

Sato, S., T. Suzuki, and K. Okada. 1995. Suppression of lymphocyte blastogenesis in cows with puerperal metritis and mastitis. J. Vet. Med. Sci. 57:373-375.

Seder, R. A. and W. E. Paul. 1994. Acquisition of lymphokine producing phenotypes by $\mathrm{CD}^{+}$cells. Annu. Rev. Immunol. 12:635-673.

Semambo, D. K., T. R. Ayliffe, J. S. Boyd, and D. J. Taylor. 1991. Early abortion in cattle induced by experimental intrauterine infection with pure cultures of Actinomyces pyogenes. Vet. Rec. 129:12-16.

Shafer-Weaver, K. A. and L. M. Sordillo. 1996. Enhancing bactericidal activity of bovine lymphoid cells during the postpartum period. J. Dairy Sci. 79:1347-1352.

Shafer-Weaver, K. A., C. M. Corl, and L. M. Sordillo. 1999. Shifts in bovine $\mathrm{CD}^{+}$subpopulations increase $\mathrm{T}$ helper-2 compared with T-helper-1 effectors cells during the postpartum period. J. Dairy Sci. 82:1696-1706.

Sheldon, I. M., D. E. Noakes, A. N. Rycroft, and H. Dobson. 2004. Effect of intrauterine administration of estradiol on postpartum uterine bacterial infection in cattle. Anim. Reprod. Sci. 81:1323.

Sukhikh, G. T., N. M. Kasabulatov, L. V. Van'ko, N. V. Ordzhonikidze, V. N. Veryasov, and S. Zh. Danelyan. 2005. Ratio between the number of Th1 and Th2 lymphocytes in the peripheral blood and concentration of pro-inflammatory cytokines in lochia of women with postpartum endometritis. Bul. Exp. Biol. Med. 140:672-674.

Usmani, R. H., N. Ahmad, P. Shafiq, and M. A. Mirza. 2001. Effect of sub-clinical uterine infections on cervical and uterine involution, estrous activity and fertility in postpartum buffaloes. Theriogenology 55:563-571. 